\title{
Embryo implantation associated with increase in T-cell suppressor factor in the uterus and spleen of mice
}

\author{
R. C. Hoversland and K. D. Beaman* \\ Department of Anatomy, Indiana University School of Medicine, Center for Medical Education. \\ Fort Wayne, Indiana 46805-1499, USA; and *Department of Immunology \& Microbiology, \\ University of Health Sciences/The Chicago Medical School, North Chicago, Illinois 60064-30954, \\ $U S A$
}

\begin{abstract}
Summary. The concentrations of T-cell suppressor factor (TsF) were examined by competitive binding assays in the uterus, spleen, and regional lymph nodes draining the uterus in Day-5 pregnant mice or in ovariectomized mice given hormone treatments to induce conditions of delayed implantation or implantation. The amounts of immunoreactive $\mathrm{TsF}$ on Day 5 of pregnancy were $2.055 \pm 0.302,0.803 \pm 0.088$, $0.426 \pm 0.136 \mathrm{ng} \mathrm{TsF} / \mathrm{mg}$ extractable protein for the regional lymph nodes, spleen and uterus, respectively, during Day 5 of pregnancy. When implantation was prevented by ovariectomy on Day 4 followed by treatment with only progesterone, amounts of TsF (as a \% of Day 5 value) were decreased to $57 \%$ in the uterus and increased to $141 \%$ in the spleen and $180 \%$ in the regional lymph nodes. When implantation was then initiated with the addition of oestradiol- $17 \beta$ to the progesterone treatment, amounts of $\mathrm{TsF}$ were increased to $206 \%$ in the uterus, $318 \%$ in the spleen, and remained unchanged at $180 \%$ in the regional lymph nodes. These experiments suggest that the amounts of TsF in the uterus and spleen are dependent upon the implantation process, whereas amounts of $\mathrm{TsF}$ in the regional lymph nodes are independent of this event.
\end{abstract}

Keywords: T-cell suppressor factor; implantation; monoclonal antibody; pregnancy; delayed implantation; mouse

\section{Introduction}

The question of why the developing fetus is not rejected as an allograft remains a central question in reproductive immunology. One possible explanation of the many explanations that have been put forth in the literature is fetal specific immune suppression (Clark \& MacDermott, 1978; Chaouat \& Voisin, 1980; Chaouat et al., 1983, 1985; Clark et al., 1984, 1986). Although the exact mechanism of fetal specific immune suppression has not been elucidated, several investigators have described antigen-specific regulation of the immune response which is controlled by antigen-specific peptide factors (TsF) secreted by T-suppressor cells (reviewed by Ishizaka, 1984; Cone et al., 1988). Western blot analysis of reproductive tissues collected from pregnant mice near term demonstrates the presence of an immunoreactive molecule with physicochemical properties similar to $\mathrm{TsF}$ (Beaman \& Hoversland, 1988). Further work has demonstrated the presence of immunoreactive TsF during pregnancy by ELISA techniques (Ribbing et al., 1988). Such studies indicate that concentrations of TsF are elevated early in pregnancy and fluctuate but remain elevated throughout pregnancy in the spleen, uterus and regional lymph nodes draining the uterus.

The importance of TsF in maintaining pregnancy is suggested by experiments with an anti-TsF monoclonal antibody, 14-30, that is specific for a TsF from a L3T4 cell line (Ferguson \& Iverson, 1986). Initial experiments were aimed at blocking antigen-specific T-cell suppression by injecting 
the monoclonal antibody 14-30 into mated Swiss/Webster mice on Days 1, 3, 5 and 9 or Days 2, 3, 4, 5 and 6, and then examining whether pregnancy was maintained until Day 17 (Beaman \& Hoversland, 1988). These studies indicated that such treatment resulted in significant decreases in the number of animals remaining pregnant at term. Subsequent studies, in which groups of pregnant animals were given injections of monoclonal antibody for intervals of 3 consecutive days, indicate that the most effective time for interfering with pregnancy was when the injections were given on Days 3, 4 and 5 of pregnancy (Ribbing et al., 1988). This information coupled with the susceptibility of interference with monoclonal antibodies would suggest that TsF made by L3T4 cells is critical in early pregnancy. The ability of the anti-TsF monoclonal antibody to interfere with pregnancy at or near the time of embryo implantation would therefore suggest that the presence of TsF is critical and possibly essential during this stage of pregnancy. The following experiments were undertaken to measure $\mathrm{TsF}$ in pregnant animals at the time of normal implantation on Day 5 of pregnancy, in ovariectomized pregnant mice during 'delayed implantation', and in ovariectomized pregnant mice in which 'delayed implantation' is terminated and 'implantation' initiated by hormone treatment.

\section{Materials and Methods}

Animals. Virgin Swiss Webster mice were placed with males and examined daily for the presence of a vaginal plug. The day of finding a vaginal plug was designated Day 1 of pregnancy. Animals were then randomly allocated to three treatment groups.

Treatment and injections. Animals in Group 1 ('normal Day 5') were killed by cervical dislocation on Day 5 of pregnancy. The uteri were flushed with a stream of saline $(0 \cdot 15 \mathrm{M}-\mathrm{NaCl})$ and those animals that contained one or more blastocysts were included in the study. The uterus, spleen, regional lymph nodes draining the uterus (posterior abdominal lymph nodes in the region of common iliac vessels), and muscle from the medial aspect of the hind leg were collected and stored at $-20^{\circ} \mathrm{C}$ until the time of assay. Animals in Group 2 ('delayed implantation') were ovariectomized via dorso-lateral incisions on Day 4 of pregnancy then injected (s.c.) daily with $2 \cdot 0$ mg progesterone (Sigma, St Louis, MO, USA) dissolved in $0.1 \mathrm{ml}$ sesame seed oil on Days 7, 8 and 9 of pregnancy. Animals were killed on Day 10 and pregnancy verified by examination for the presence of blastocysts in uterine flushings. The uterus, spleen, regional draining lymph nodes, and leg muscles were collected and frozen. Animals in Group 3 ('induced implantation') were ovariectomized on Day 4 of pregnancy and injected (s.c.) with $2.0 \mathrm{mg}$ progesterone in $0.1 \mathrm{ml}$ sesame seed oil on Days 7 and 8 and with $25 \mathrm{ng}$ oestradiol-17 $(\mathrm{Sigma}$ ) in combination with $2.0 \mathrm{mg}$ progesterone on Day 9 . Animals were killed on Day 10, the presence of blastocysts verified, and the uterus, spleen, regional lymph nodes, and leg muscle were collected and frozen.

Tissue preparation. Tissues were placed in 2 volumes of a phosphate-buffered saline (PBS, $0 \cdot 15 \mathrm{M}^{-\mathrm{NAH}_{2}} \mathrm{PO}_{4} /$ $\mathrm{Na}_{2} \mathrm{HPO}_{4}, 0.15 \mathrm{M}-\mathrm{NaCl}, \mathrm{pH} 7.4$ ) containing $0.5 \%$ Triton-X 100 and homogenized on ice using a Polytron tissue grinder (Brinkman Instruments, Westbury, NY, USA). The homogenates were then centrifuged at $1500 \mathrm{~g}$ for $15 \mathrm{~min}$ at $4{ }^{\circ} \mathrm{C}$. The pellet was discarded and the supernatant fluid subjected to $50 \%$ ammonium sulphate precipitation. The pellet was then resuspended into PBS with $0.5 \%$ Triton-X 100 and assayed for TsF.

Cells. The cells producing monoclonal antibody 14-30 were obtained from Dr T. Ferguson (Emory University, Atlanta, GA, USA) and cultured on DMEM with $10 \%$ fetal calf serum as described previously (Ferguson et al., 1985). The culture medium was harvested and concentrated 10 -fold by precipitation with $50 \%$ ammonium sulphate. The precipitate was dialysed into PBS.

Affinity purification of $\boldsymbol{T s} \boldsymbol{F}$. The entire uterus and uterine contents were collected from Day-17 pregnant mice and homogenized as described above under 'Tissue preparation' and centrifuged at $1500 \mathrm{~g}$ for $15 \mathrm{~min}$ at $4^{\circ} \mathrm{C}$. The supernatant solution was then diluted with 3 volumes of borate-buffered saline $(0 \cdot 17 \mathrm{M}$-borate, $0 \cdot 12 \mathrm{M}-\mathrm{NaCl}, \mathrm{pH} 8 \cdot 0)$ and subjected to affinity chromatography using Sepharose immunoabsorbent columns as previously described (Ferguson et al., 1985).

Assay for $\boldsymbol{T} \boldsymbol{s}$ F. Flat-bottomed microtitre trays (Immunlon-Dynatech, McLean, VA, USA) were coated overnight with $10.0 \mu \mathrm{g}$ affinity-purified TsF per 96 wells of affinity-purified TsF in $0.1 \mathrm{M}$-sodium bicarbonate buffer (pH 9.25). Plates were then blocked with $100 \mu \mathrm{l} 0 \cdot 1 \%$ bovine serum albumin/well in the same buffer for $1 \mathrm{~h}$ at $37^{\circ} \mathrm{C}$. Sample homogenates were serially diluted $(1: 2)$ in $0.1 \mathrm{M}$-potassium phosphate buffer (pH $\left.7 \cdot 4\right)$ containing $0.1 \%$ Triton-X 100 and $0.5 \%$ gelatin. After the addition of the prepared tissue extracts or the affinity-purified TsF standards, $100 \mu \mathrm{l}$ assay buffer containing monoclonal antibody $14-30$ were added to each well and incubated at $37^{\circ} \mathrm{C}$ for $1 \mathrm{~h}$. The plates were then washed 3 times with the assay buffer, followed by a $1-\mathrm{h}$ incubation with alkaline phosphatase-conjugated anti-rat immunoglobulin (1:1000 dilution, heavy and light chain; Boehringer Mannheim Biochemicals, Indianapolis, IN, USA). The plates were then washed again and incubated with a substrate solution 
containing I mg p-nitrophenylphosphate/ml (Sigma) in $0.15 \mathrm{M}$-diethanolamine $\mathrm{HCl}$ buffer (pH 9.25) and allowed to develop for $1-3 \mathrm{~h}$ at $37^{\circ} \mathrm{C}$. The absorbance of the reaction product formed was determined by a Minireader II (Dynatech, McLean, VA, USA) at $410 \mathrm{~nm}$. Protein amounts were determined by the method of Bradford (1976) using bovine serum albumin as standards (Fraction V, Sigma). The amounts of TsF in each well were calculated using linear regressions of the logit binding versus log dose (Rodbard, 1974) of the affinity-purified TsF standards. The amount of TsF was normalized to extracted precipitated protein content and the data presented as a percentage of that on Day 5 of pregnancy. One-way ANOVA followed by Student's $t$ tests were performed to determine whether each treatment resulted in a significant difference from that in the tissues of normal Day 5 pregnant mice.

\section{Results}

The TsF content was measurable in the Day-5 uterus, spleen, and regional draining lymph nodes but was not detected in medial leg muscle used as a negative control. The content of immunoreactive $\mathrm{TsF}$ (mean \pm s.e.m. $\mathrm{ng} \mathrm{TsF} / \mathrm{mg}$ extractable protein) was $2.055 \pm 0.302(n=5)$ in the draining lymph nodes, $0.803 \pm 0.088(n=5)$ in the uterus, and $0.426 \pm 0 \cdot 136(n=5)$ in the spleen. The amount of TsF was decreased in uteri of Group 2 mice to $57 \pm 17 \%(P<0.05, n=5)$ of that of Group 1 mice and increased to $206 \pm 46 \%(P<0.05, n=5)$ in uteri of Group 3. In the spleen, the amounts of TsF were $141 \pm 33 \%(P>0.05, n=5)$ and $318 \pm 61 \%(P<0 \cdot 05, n=5)$ in mice in Groups 2 and 3, respectively, and in the regional lymph nodes, values were increased to $169 \pm 24 \%(P<0.05, n=3)$ and $180 \pm 70 \%(P>0.05, n=3)$ in mice in Groups 2 and 3 , respectively.

The treatment for mice in Groups 2 and 3 differed only in one $25 \mathrm{ng}$ injection of oestradiol-17 $24 \mathrm{~h}$ before tissues were collected and resulted in significant differences $(P<0.05$ when compared with each other) in the amounts of TsF in the spleen and uterus, but not in the regional lymph nodes draining the uterus. The induction of embryo implantation by injection of oestradiol-17 $\beta$ caused a 5-fold increase in amount of TsF present in the uterus and nearly a 3-fold increase in the TsF content of the spleen. The induction of implantation did not appreciably change the TsF content in the draining lymph nodes. The prevention of implantation increased the amount of TsF in the spleen and lymph nodes while the quantity of TsF was lower in the uterus.

\section{Discussion}

These results confirm the earlier observations of TsF found in the uterus, spleen, and regional lymph nodes of the pregnant mouse (Beaman \& Hoversland, 1988). In addition, these data support the increases in TsF observed during early pregnancy (Ribbing et al., 1988) and extend our understanding of immune suppression during early pregnancy, with the present finding that amounts of $\mathrm{TsF}$ in the spleen and uterus are elevated in a pattern that is coincident with the process of implantation. Others have reported that suppressor cells are present during early pregnancy and that some populations appear to be under hormonal control. Clark \& McDermott (1981) described a population of small suppressor cells in the lymph nodes draining the uterus during the preimplantation period and a population of apparently hormone responsive suppressor cells with larger cell size present in both the uterus and regional lymph nodes has been demonstrated by Brierley \& Clark (1987). Although soluble suppressor factor could not be demonstrated by Brierley \& Clark (1987), the suppressor cells present in the uterus and regional lymph nodes were positive for Lyt2.1 and L3T4. This finding is similar to those of Thomas \& Erickson (1986) who reported Thy $1+$ and Lyt $2+$ suppressor cells in the lymph nodes after mating. The monoclonal antibody 14-30 used in these present experiments to assay TsF is specific for the suppressor factor elaborated by a L3T4 cell (Ferguson \& Iverson, 1986) and the present findings are therefore consistent with the concept of hormone-sensitive L3T4 suppressor cells present in the uterus during early pregnancy.

Implantation is an hormonally controlled event in mice and the absence of oestrogen is associated with a delay in implantation (Whitten, 1955, 1958; Yoshinaga \& Adams, 1966; Weitlauf \& 
Greenwald, 1968). During this time the embryo becomes metabolically quiescent with the rate of cell division slowing and the synthetic rate of protein, DNA, RNA and $\mathrm{CO}_{2}$ production all decreased. At the time oestrogen is added to the treatment regimen these indices increase as the embryo becomes metabolically active and implantation occurs. In the present experiment, the time of embryonic quiescence was accompanied by a decreased level of TsF in the uterus compared to Day 5 of pregnancy and an increase in both the uterus and spleen when implantation was induced. Several possibilities would account for such an increase. These would include hormonal stimulation of the suppressor cells similar to those described by Brierley \& Clark (1987), a dependence upon the specific embryonic events such as increased metabolic activity associated with initiation of implantation, and increased presentation of the antigen, possibly by lysis of the zona pellucida or physical contact between the embryo and endometrium before the attachment that occurs $36 \mathrm{~h}$ after oestradiol-17 $\beta$ (Hoversland \& Weitlauf, 1981). Furthermore, on the basis of the present experiments it cannot be ruled out that the increase in apparent TsF is due to an increase in some other factor with cross-reactivity. Such 'activity' would appear to play an important, possibly essential, role in pregnancy since the critical period during pregnancy that this monoclonal antibody has antipregnancy effects when injected in vivo coincides with the time of implantation (Beaman \& Hoversland, 1988; Ribbing et al., 1988). Further experiments are needed to separate these possibilities.

Although amounts of TsF present in the uterus and spleen differed between the two conditions of 'implantation' and 'delayed implantation', there was no marked difference between the amounts of $\mathrm{TsF}$ present in the regional lymph nodes in these two conditions. This may indicate active suppression in local lymph organs draining the uterus at a time of a reduced level of suppression in the uterus during the time embryos are kept in a state of delay. If suppression is essential for the extended length of time that embryos can be kept in delay, then the suppression occurring in local lymph nodes would appear to be of greater importance than that in the uterus. Furthermore, the maintenance of such suppression if hormone responsive would appear to be progesteronedependent since mice in this treatment group did not receive oestrogen. That portion of the increased amounts of TsF present in the uterus and spleen triggered by the mere presence of quiescent embryos during delayed implantation or by active embryos at the time of implantation remains to be determined and will be the focus of future experiments.

We thank D. Brist and D. Grissom for technical assistance and D. Jackson for matıuscript preparation. This work was supported in part by grants from Life and Health Insurance Medical Research Fund and NIH grants, BRSG RR-05366-24 and HICHHD HD 18095.

\section{References}

Beaman, K.D. \& Hoversland, R.C. (1988) Induction of abortion in mice with a monoclonal antibody specific for suppressor T-lymphocyte molecules. J. Reprod. Fert. 82, 691-696.

Bradford, M.M. (1976) A rapid and sensitive method for the quantitation of microgram quantities of protein utilizing the principle of protein-dye binding. Analyt. Biochem. 72, 248-254.

Brierley, J. \& Clark, D.A. (1987) Characterization of hormone-dependent suppressor cells in the uterus of mated and pseudopregnant mice. J. Reprod. Immunol. 10, 201-217.

Chaouat, G. \& Voisin, G.A. (1980) Regulatory T-cell subpopulations in pregnancy. II. Evidence for suppressive activity of the late phase of MLR. Immunology 39, 239-248.
Chaouat, G., Kolb, J. \& Wegmann, T. ( 1983) The mucosa and placenta as an immunological barrier between the mother and fetus. Immunol. Rev. 75, 31-60.

Chaouat, G., Kolb, J., Kiger, N., Stanislowski, M. \& Wegmann, T. (1985) Immunologic consequences of vaccination against abortion in mice. $J$. Immunol. 134, 1594-1598.

Clark, D.A. \& MacDermott, M.R. (1978) Impairment of host versus graft reaction in pregnant mice. II. Selective suppression of cytotoxic cell generation correlates with soluble suppressor activity and with successful allogenic pregnancy. Cell Immunol. 52, $106-118$.

Clark, D.A. \& MacDermott, M.R. (1981) Active suppression of host-vs-graft reaction in pregnant mice. III. Development kinetics, properties, and the 
mechanism of induction of suppressor cells during first pregnancy. J. Immunol. 127, 1267-1273.

Clark, D., Slapsys, R., Croy, B., Kreek, J. \& Rossant, J. (1984) Local active suppression by suppressor cells in the decidua. Am. J. Reprod. Immunol. 5, 78-83.

Clark, D., Caput, A. \& Tutton, D. (1986) Spontaneous abortion of allogeneic $\mathrm{CBA} / \mathrm{J} \times \mathrm{DBA} / 2$ fetuses in the uterus of CBA/J mice correlated with deficient non-T suppressor cell activity. $J$. Immunol. 136, $1668-1675$.

Cone, R.E., Zheng, H., Chue, B., Beaman, K., Ferguson, T. \& Green, D.R. (1988) T-Cell derived antigen binding molecules (TABM): Molecular and functional properties. Int. Rev. Immunol. 3, 205-228.

Ferguson, T. \& Iverson, G. (1986) Isolation and characterization of an antigen specific inducer molecule from the serum of hyperimmune mice using a monoclonal antibody. J. Immunol. 136, 2896-2903.

Ferguson, T., Beaman, K. \& Iverson, G. (1985) Isolation and characterization of a $\mathbf{T}$-suppressor factor by using a monoclonal antibody. J. Immunol. 134, 3163-3171.

Hoversland, R.C. \& Weitlauf, H.M. (1981) Lysis of the zona pellucida and attachment of embryo to the uterine epithelium in ovariectomized mice treated with oestradiol-17 $\beta$ and progesterone. J. Reprod. Fert. 62, $111-116$.
Ishizaka, K. (1984) Regulation of IgE synthesis. Ann. $R$. Immunol. 2, 159-182.

Ribbing, S.L., Hoversland, R.C. \& Beaman, K.D. (1988) T-cell suppressor factors play an integral role in preventing fetal rejection. J. Reprod. Immunol. 14, 83-95.

Rodbard, D. (1974) Statistical quality control and routine data processing for radioimmunoassays and immunoradiometric assays. Clin. Chem. 20, $1255-1270$.

Thomas, I.K. \& Erickson, K.L. (1986) Gestational immunosuppression is mediated by specific Lyt $2+\mathrm{T}$ cells. Immunology 57, 201-206.

Weitlauf, H.M. \& Greenwald, G.S. (1968) Survival of blastocysts in the uteri of ovariectomized mice. J. Reprod. Fert. 17, 515-520.

Whitten, W.K. (1955) Endocrine studies on delayed implantation in lactating mice. J. Endocr. 13, 1-6.

Whitten, W.K. (1958) Endocrine studies on delayed implantation in lactating mice. Role of the pituitary in implantation. J. Endocr. 16, 435-440.

Yoshinaga, K. \& Adams, C.E. (1966) Delayed implantation in the spayed progesterone treated adult mouse. $J$. Reprod. Fert. 12, 593-595.

Received 17 March 1989 